\title{
Mechanism of action of bio-inspired nanosilver particles
}

Qurat-Ul-Ain PhD

PhD Scholar, Department of Chemistry, University of Agriculture,

Faisalabad, Pakistan (corresponding author: qurat29111990@gmail.com)

Raja Adil Sarfraz PhD

Assistant Professor, Department of Chemistry and Officer In-charge Central

Hi-tech lab, University of Agriculture, Faisalabad, Pakistan

\author{
Abdul Qayyum MPhil \\ PhD Scholar, Department of Chemistry, College of Science, Shantou \\ University, Guangdong, P.R. China
}

Nanotechnology is gaining prime importance in the present era due to modeling of metals in nanoparticles (NPs) by biological methods, but nowadays, researchers are designing the exact mode of action of nanomaterials on plants. NPs are fabricated by different physical and chemical methods, but biological methods are preferred due to their simplicity and non-toxic nature. The current development of biomimetic NP synthesis is a more reliable, economically favorable and eco-friendly method for the treatment of different diseases. NPs fabricated by traditional methods have shown a lot of demerits, so the green route to the formation of metallic NPs is advantageous compared to the use of microbes. Secondary metabolites in the plant have active chemical constituents which can act as capping and reducing agents, thereby enhancing the rate of reduction and stabilizations of NPs. In this review, a major focus is given to biogenic silver NPs' mechanism of action toward cancer and microbes.

\section{Introduction}

Nanoparticles (NPs) include particles with sizes from 1 to $100 \mathrm{~nm} .{ }^{1}$ Nanotechnology focuses mainly on the synthesis, design, size of particles in nanodimension and the manipulation of their structures. ${ }^{2}$ Richard Feynman ${ }^{3}$ first gave the concept of nanotechnology in 1959. Nanotechnology is now creating new innovations and inventions in the field of medical sciences as well as biomedical devices. ${ }^{4}$

Metal NPs have been reported to have excellent chemical reactivity and potential applications in biosensing, drug delivery, detection of genetic disorders, gene therapy, catalysis, surfaceenhanced Raman scattering, photography and DNA sequencing (Figure 1). ${ }^{5}$

NPs have unique properties compared to microparticles, with regard to shape, size and distribution. ${ }^{6}$ Silver (Ag)-based compounds have been used in medical applications since the nineteenth century. ${ }^{7}$ Silver nanoparticles (SNPs) have been used as antimicrobial agents in elevators and railway stations in China. ${ }^{8}$ Silver is usually used in the form of silver nitrate $\left(\mathrm{AgNO}_{3}\right)$ to induce antimicrobial effects; when silver is used at the nanoscale, its enhanced surface area increases the magnitude of action toward microbes. SNPs can inhibit cell transduction, cell lysis and growth. ${ }^{9}$

Current studies have revealed that the use of SNPs in the treatment of wound healing causes reduction of local matrix metalloproteinase activity and enhances neutrophil apoptosis within the wounds. ${ }^{10}$ When SNPs were introduced in a rat model with burn injury, these caused reduction in the level of proinflammatory cytokines; SNPs play a vital role in the inhibition of the tumor necrosis factors alpha and activities of interferon gamma, which are responsible for inflammation. ${ }^{11,12}$
Nanosilver-based design for wound dressing was first discovered by Dr Robert Burrell in 1995. The name of the dressing was Acticoat; nowadays, it is being sold worldwide by Smith and Nephew. ${ }^{13}$ SNPs are coated with polymethyl methacrylate and used in bone cements as artificial joint replacements. When polypropylene mesh was coated over nanosilver particles, it showed tremendous antimicrobial activity. ${ }^{14}$

A proto-oncogene is a normal gene that regulates cell growth in a controlled fashion, but it can be converted into an oncogene by way of mutations and overexpression. Activated oncogenes are responsible for inducing tumor and cancer in healthy cells. Cancer is the fastest spreading and most fatal disease all over the world; malignant cells undergo rapid and uncontrolled cell division in the human body. ${ }^{15}$

Cancer cells proliferate through different steps of mutation, on which anticancer drugs exert their mechanisms of action (Figure 2). The philosophy of using anticancer drugs is to inhibit one or more actions/steps of mechanisms of cancer cell proliferation or inhibit an organelle to work for the cells.

\section{Methods of NP fabrication}

NPs are fabricated by physical, chemical and biological methods. SNPs $(3-40 \mathrm{~nm})$ are obtained by chemical reduction of metal slat of silver tetrafluoroborate $\left(\mathrm{AgBF}_{4}\right)$ by sodium borohydride in water. ${ }^{16}$ Very expensive conventional methods have been used for the fabrication of NPs while showing hazardous effects (Figure 3).

Thus, scientists have put their attention toward using green synthesis for the formation of NPs due to obtain their precise shape and controlled structures. Two approaches are preferred: top-down and bottom-up (Figure 4). ${ }^{17}$ 
Bioinspired, Biomimetic and Nanobiomaterials Volume 7 Issue BBN3
Mechanism of action of bio-inspired nanosilver particles

Qurat-Ul-Ain, Sarfraz and Qayyum

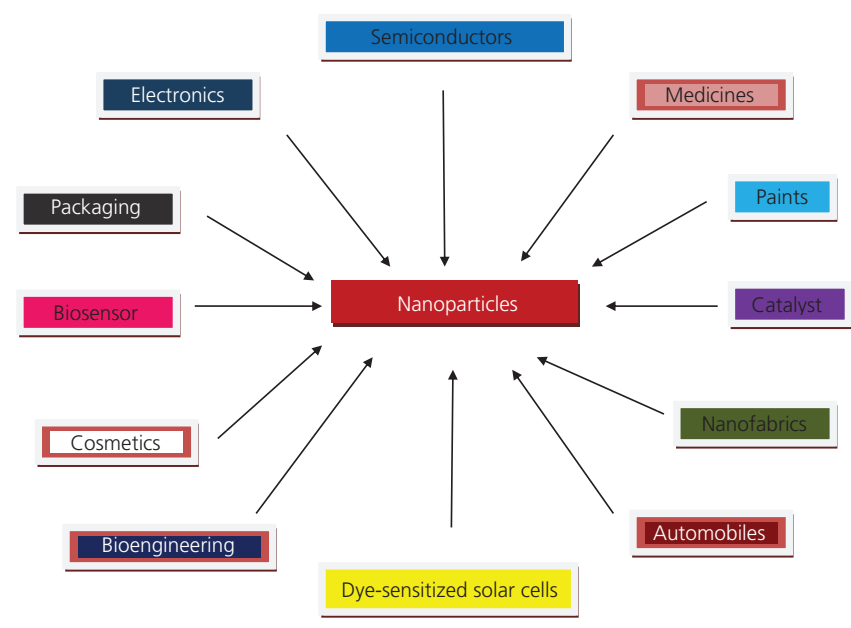

Figure 1. Applications of NPS

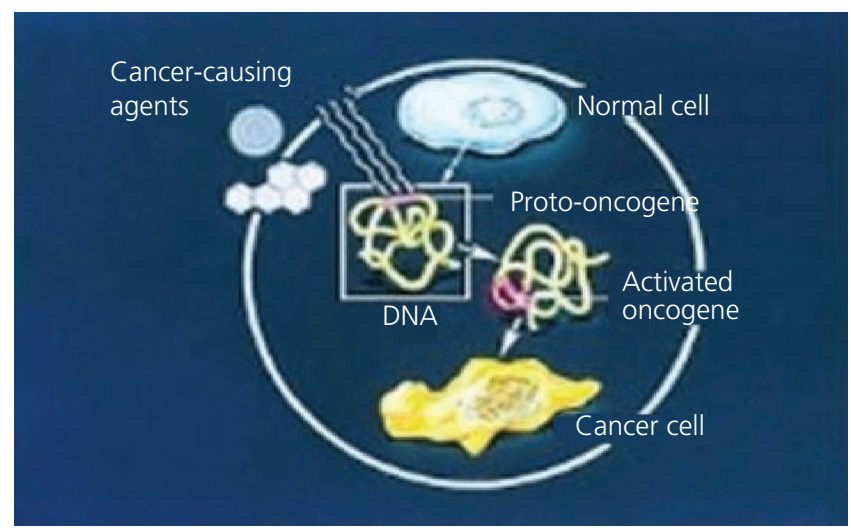

Figure 2. Mechanism of formation of oncogenes

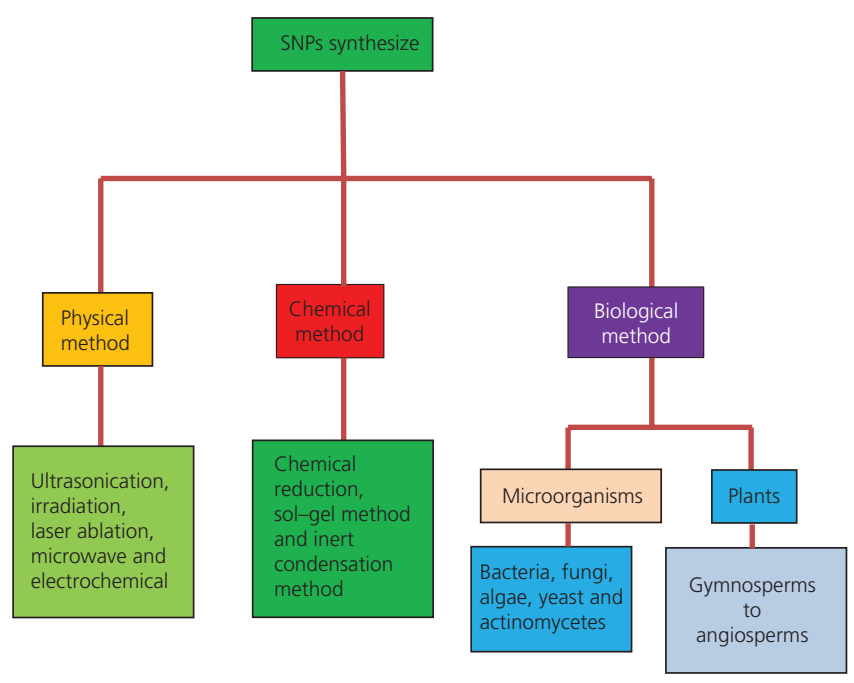

Figure 3. Method of NP synthesis

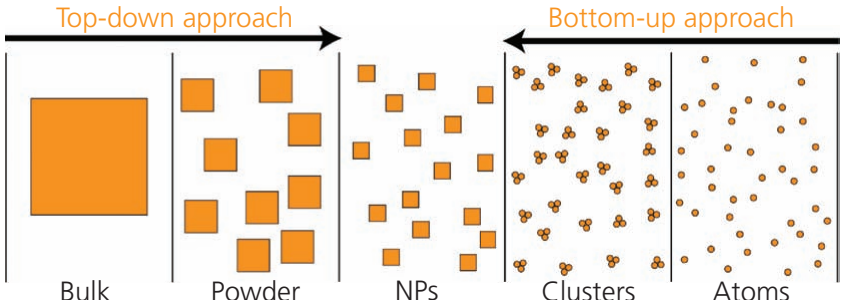

Figure 4. Approaches to NP formation

- Top-down approach: The lithographic technique is used to break down the bulk material particles into nanoscale size. ${ }^{18}$

- Bottom-up approach: Atoms are self-assembled by electrochemical deposition and sonodecomposition to form new nuclei, which grow into NPs of desired sizes.

\section{Green synthesis of nanosilver particles}

\subsection{Role of microorganisms in NP fabrication}

Amulyavichus et al. ${ }^{19}$ first reported that SNPs were isolated from silver mine using Pseudomonas stutzeri AG259. The mechanisms involved in the resistance of microorganisms are responsible for alteration of solubility and toxicity by way of reduction. ${ }^{20}$ In vitro synthesis by silver using bacteria (Bacillus licheniformis) causes secretion of alpha nicotinamide adenine dinucleotide phosphate (NADP) and NADPH enzymes, which are responsible for nitrate reductase, which efficiently converts silver ion into metallic silver (Figure 5). ${ }^{21}$

If the formations of SNPs by bacteria and fungi are compared, fungi show outstanding production of NPs compared with bacteria due to the ability of fungi to emit a greater amount of proteins that directly translates to enhance the production of NPs. ${ }^{22}$

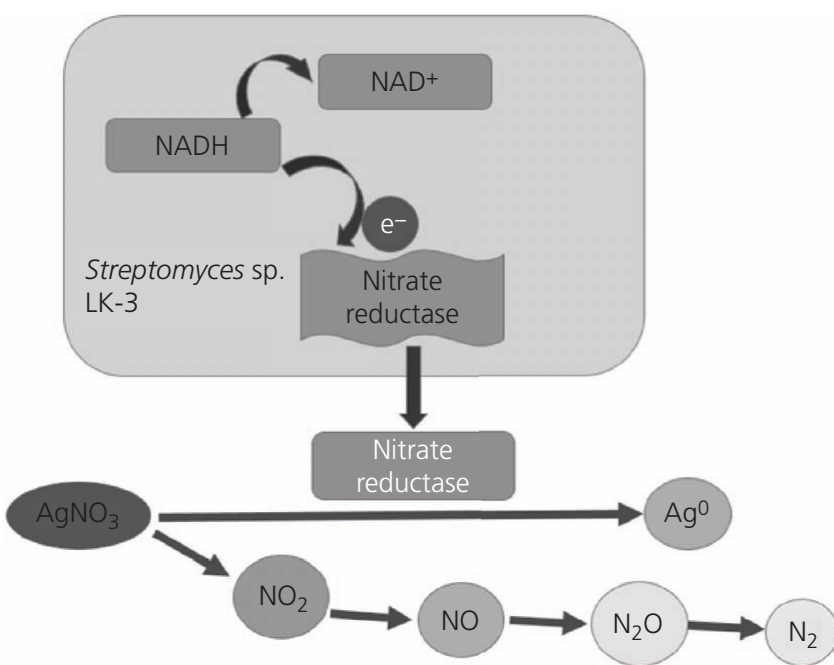

Figure 5. SNP formation by bacteria 
Extracellular enzymes such as naphthoquinones and anthraxquinones present in fungi are accountable for trapping silver ions at the surface of fungal cells and reduction of silver ions $\left(\mathrm{Ag}^{+}\right)$ into metallic silver (Figure 6). ${ }^{23,24}$

\subsection{Phytofabrication of SNPs}

Plant extracts could be utilized as a source for the fabrication of SNPs; chemical constituents such as secondary metabolites present in plant extracts act as reducing and capping agents. Silver nitrate, aurum chloride and titanium chloride have been used for the formation NPs such as silver, gold and titanium by using plant extracts. ${ }^{25,26}$

Plants consist of a complicated set of antioxidant metabolites and enzymes that work against oxidative damage to cellular components. Phytochemicals such as polyphenols, ascorbic acid, triterpenes, alkaloids, alcoholic compounds, saponins, flavonoids, sterols, fructose, glucose, protein and $\beta$-phenylethylamines have been used for the reduction of silver ion into metallic silver. $^{22,27-29}$

Different parts of plants contain a variety of functional groups of secondary metabolites that cause reduction of silver ions. ${ }^{30,31}$ After the formation of SNPs, characterization of NPs by using different surface techniques - for example, SEM - is then carried out to determine the morphology of NPs at submicron to micron scales.

Fourier-transform infrared spectroscopy can be used to identify functional groups attached to the surface of NPs, whereas X-ray powder diffraction is used to determine the crystal structure and phase identification of NPs. ${ }^{32,33}$ Metallic NPs have been synthesized by using different phytoextracts shown in Table 1.

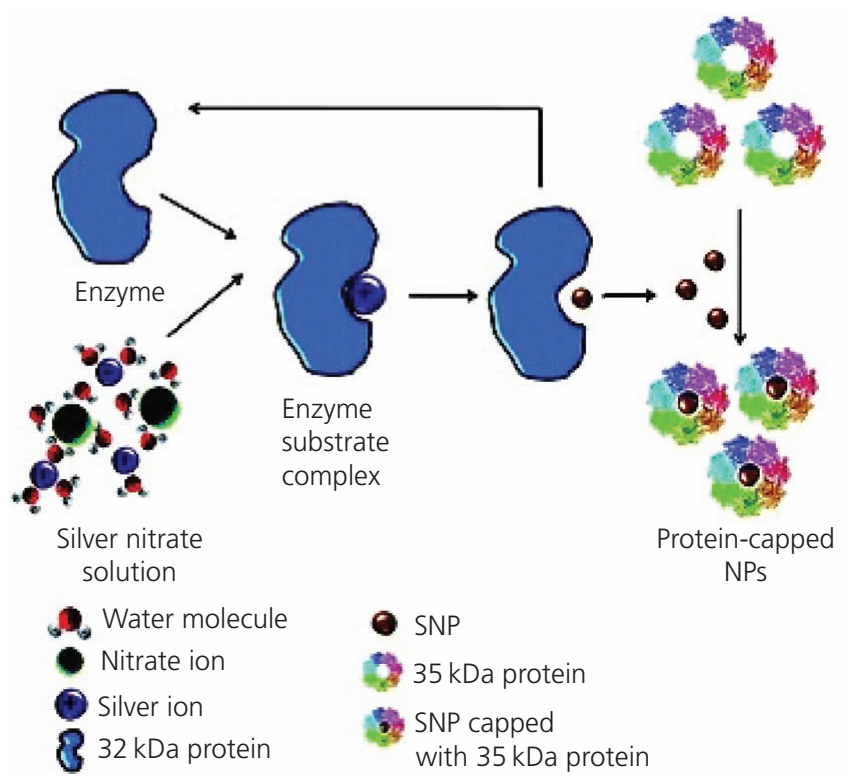

Figure 6. SNP formation by fungi

\section{Mechanism of action of SNPs toward microbes}

Silver metal has been used in people's daily life for different purposes such as jewelry, ornamentation and fine cutlery. Silver is the only metal which has the potential to resist microbes, dating back to the Phoenicians. Silver is used as an antimicrobial agent to fight against many microorganisms, numbering approximately 650 from diverse modules such as gram-negative and grampositive bacteria, fungi and viruses.

In 1884, aqueous silver nitrate was used in the form of eye drops for newborn babies to prevent the transmission of Neisseria gonorrhoeae from infected mothers. Metals have many properties; silver is the metal that shows the least toxic effect in in vivo and in vitro. ${ }^{46}$

Silver is usually used in the form of salt, mostly silver nitrate, to show antimicrobial effect, but when SNPs are used, their physical parameters eventually changed, such as when huge surface areas have been exposed for the microbes. Biogenic SNPs have been used for evaluating their antimicrobial activities against different microbes. The antimicrobial properties of biofabricated SNPs are based on size, environmental conditions and capping agent. SNPs have a significant action against microbes; they have the ability to anchor to a bacterial cell and penetrate it (Figure 7). Silver is inert, but when it is in contact with moisture, it releases silver ions, so a positive charge indicating silver ions is reported to be vital for antimicrobial activities. ${ }^{133}$

Silver ions are able to form complexes with nucleic acids and preferentially interact with the nucleosides rather than with the phosphate groups of nucleic acids. Silver ions are obtained from silver or silver-containing compounds with notable antimicrobial properties; these silver ions may be incorporated into the substance and released slowly with time. ${ }^{134}$ Researchers have reported that a suitable bactericidal agent is formed due to a strong electrostatic force of attraction between positively charged SNPs and negatively charged bacterial cells. ${ }^{132,135,136}$ Two mechanisms have been reported for SNP resistance toward microbes.

\subsection{First mechanism}

SNPs can easily permeate into bacterial cell walls and cause cell death by changing the structure of bacteria; thus, pits that have formed on the cell surface of bacteria provide a way for NPs to accumulate. ${ }^{134}$ Ankanna et al. ${ }^{46}$ reported that SNPs have been shown to accumulate inside the membrane and can subsequently penetrate into the cells then causing injury to the cell wall or cell membranes.

The exact mode of action of SNPs is that they bind to thiol groups $(\mathrm{SH})$ of enzymes and then form the stable $\mathrm{S}-\mathrm{Ag}$ bonds with thiol-containing compounds and are responsible for the deactivation of enzymes such as transmembrane energy generation and ion transport in the cell membrane.

When silver ions enter cells, these intercalate between the purine and pyrimidine base pairs, disrupting the hydrogen bonds between 
Bioinspired, Biomimetic and Nanobiomaterials Volume 7 Issue BBN3
Mechanism of action of bio-inspired

nanosilver particles

Qurat-Ul-Ain, Sarfraz and Qayyum

Table 1. Some phytofabricated nanoparticles (continued on next pages)

\begin{tabular}{|c|c|c|c|c|c|}
\hline Plant & Plant parts & Biomolecules involved & Type of NP & Size and shape & References \\
\hline Acalypha indica & Leaf & Quercetin & Silver & 20-30 nm; spherical & Sun et al..$^{34}$ \\
\hline $\begin{array}{l}\text { Achyranthus } \\
\text { aspera }\end{array}$ & Leaf & Polyols & Silver & 20-30 nm; spherical & Krishnaraj et al. ${ }^{35}$ \\
\hline Allium sativum & Leaf & Sucrose and fructose & Silver & 4-22 nm; spherical & Daniel et al. ${ }^{36}$ \\
\hline Aloe vera & Leaf & Proteins & Silver, gold & $\begin{array}{l}\text { 50-350 nm; } \\
\text { spherical and } \\
\text { triangular }\end{array}$ & Von White et al. ${ }^{37}$ \\
\hline $\begin{array}{l}\text { Azadirachta } \\
\text { indica }\end{array}$ & Leaf & $\begin{array}{l}\text { Salanin, nimbin, azadirone and } \\
\text { azadirachtin }\end{array}$ & Silver, gold & $\begin{array}{l}7 \cdot 5-6.5 \mathrm{~nm} \text {; } \\
\text { spherical, } \\
\text { triangular, } \\
\text { quasi-spherical }\end{array}$ & Chandran et al. ${ }^{38}$ \\
\hline $\begin{array}{l}\text { Astragalus } \\
\text { gummifer }\end{array}$ & Leaf & Proteins & Silver & $\begin{array}{l}13 \cdot 1 \pm 1 \cdot 0 \mathrm{~nm} \\
\text { spherical }\end{array}$ & Thirumurugan et al. ${ }^{39}$ \\
\hline $\begin{array}{c}\text { Andrograhis } \\
\text { paniculata }\end{array}$ & Leaf & Hydroxyflavones; catechin & Silver & $28 \mathrm{~nm}$; spherical & Kora and Arunachalam ${ }^{40}$ \\
\hline $\begin{array}{l}\text { Anacardium } \\
\text { occidentale }\end{array}$ & Leaf & Polyols and proteins & $\begin{array}{l}\text { Gold, silver, gold } \\
\text { core-silver shell, } \\
\text { gold-silver alloy }\end{array}$ & - & Jayashree and Vani ${ }^{41}$ \\
\hline Allium сера & Leaf & Vitamin C & Gold & $\begin{array}{l}\text { Approximately } \\
100 \mathrm{~nm}\end{array}$ & Sheny et al. ${ }^{42}$ \\
\hline Avena sativa & Leaf & Phenolics & Gold & $6-20 \mathrm{~nm}$ & Parida et al. ${ }^{43}$ \\
\hline $\begin{array}{l}\text { Argemone } \\
\text { Mexicana }\end{array}$ & Leaf & Terpenoid & Silver & - & Shankar et al. ${ }^{44}$ \\
\hline $\begin{array}{l}\text { Boswellia } \\
\text { ovalifoliolata }\end{array}$ & Leaf & Tannins and quinines & Silver & $30-40 \mathrm{~nm}$ & Singh et al. ${ }^{45}$ \\
\hline Brassica juncea & Leaf & Oxalic acid & Gold & - & Ankanna et al. ${ }^{46}$ \\
\hline $\begin{array}{l}\text { Bacopa } \\
\text { monniera }\end{array}$ & Leaf & Phenolics & Silver & $15-120 \mathrm{~nm}$ & Marshall et al. ${ }^{47}$ \\
\hline $\begin{array}{l}\text { Boswelliaovali } \\
\text { foliolata }\end{array}$ & $\begin{array}{c}\text { Bark and } \\
\text { leaf }\end{array}$ & Polyols, heterocyclic components & Silver & - & Mahitha et al. ${ }^{48}$ \\
\hline $\begin{array}{l}\text { Bauhinia } \\
\text { variegate }\end{array}$ & Leaf & Polyphenols or flavonoids & Gold & $43-145 \mathrm{~nm}$ & Jha et al. ${ }^{49}$ \\
\hline $\begin{array}{l}\text { Cinnamomum } \\
\text { camphora }\end{array}$ & Leaf & Polyols, heterocyclic components & Gold and silver & $55-80 \mathrm{~nm}$ & Kumar and Yadav ${ }^{50}$ \\
\hline $\begin{array}{l}\text { Capsium } \\
\text { annuum }\end{array}$ & Leaf & Proteins & Silver & $15-20 \mathrm{~nm}$ & Huang et al. ${ }^{51}$ \\
\hline $\begin{array}{l}\text { Cinnamomum } \\
\text { zeylanicum }\end{array}$ & Leaf & Terpenoid & Silver & $50-100 \mathrm{~nm}$ & Li et al. ${ }^{25}$ \\
\hline Carica papaya & Leaf & Hydroxyflavones and catechins & Silver & $15 \mathrm{~nm}$ & Sathishkumar et al. ${ }^{52}$ \\
\hline Coriander & Leaf & Proteins and amino acids & Gold & $6 \cdot 75-57.91 \mathrm{~nm}$ & Kora and Arunachalam ${ }^{40}$ \\
\hline $\begin{array}{l}\text { Cariandrum } \\
\text { sativum }\end{array}$ & Leaf & Terpenoid, flavonoids & Silver & $26 \mathrm{~nm}$ & $\begin{array}{l}\text { Narayanan and } \\
\text { Sakthivel }\end{array}$ \\
\hline Curcuma longa & Leaf & Flavones, alkaloid or proteins & Silver & - & Sathyavathi et al..$^{54}$ \\
\hline $\begin{array}{l}\text { Catharanthus } \\
\text { roseus }\end{array}$ & Leaf & Proteins and amino acids & Silver & $48-67 \mathrm{~nm}$ & Sathishkumar et al. ${ }^{55}$ \\
\hline Camellia sinensis & Leaf & Polyphenolic compounds & Gold & $25 \mathrm{~nm}$ & Kannan et al. ${ }^{56}$ \\
\hline Centella asiatica & Leaf & Terpenoid, flavonoids & Silver & - & Boruah et al. ${ }^{57}$ \\
\hline $\begin{array}{l}\text { Chenopodium } \\
\text { album }\end{array}$ & Leaf & Oxalic acid & Silver, gold & $12,10 \mathrm{~nm}$ & Palaniselvam et al. ${ }^{58}$ \\
\hline $\begin{array}{l}\text { Coleus } \\
\text { aromaticus }\end{array}$ & Leaf & Flavonoids & Silver & $40-50 \mathrm{~nm}$ & Dwivedi and Gopal ${ }^{59}$ \\
\hline Cycas circinalis & Leaf & Proteins and amino acids & Silver & $2-6 \mathrm{~nm}$ & Vanaja and Annadurai ${ }^{60}$ \\
\hline $\begin{array}{l}\text { Citrullus } \\
\text { colocynthis }\end{array}$ & Leaf & $\begin{array}{l}\text { Polyphenols with aromatic ring and } \\
\text { bound amide region }\end{array}$ & Silver & $31 \mathrm{~nm}$ & Jha et al. ${ }^{49}$ \\
\hline $\begin{array}{l}\text { Chrysanthemum } \\
\text { morifolium }\end{array}$ & Leaf & Flavonoids & Silver & 20-50 nm; spherical & Priya et al. ${ }^{61}$ \\
\hline $\begin{array}{l}\text { Chrysopogon } \\
\text { zizanioides }\end{array}$ & Leaf & Terpenoid & Silver & 85-110 nm, cubic & He et al. ${ }^{62}$ \\
\hline $\begin{array}{l}\text { Chrysanthemum } \\
\text { indicum }\end{array}$ & Leaf & Polyphenols or flavonoids & Silver & $\begin{array}{l}37.71-71.99 \mathrm{~nm} ; \\
\text { spherical }\end{array}$ & $\begin{array}{l}\text { Arunachalam and } \\
\text { Annamalai }^{63}\end{array}$ \\
\hline Datura metel & Leaf & $\begin{array}{l}\text { Plastohydroquinone or } \\
\text { plastrocohydroquinol }\end{array}$ & Silver & $16-40 \mathrm{~nm}$ & Arokiyaraj et al. ${ }^{64}$ \\
\hline
\end{tabular}


Table 1. Continued

\begin{tabular}{|c|c|c|c|c|c|}
\hline Plant & Plant parts & Biomolecules involved & Type of NP & Size and shape & References \\
\hline $\begin{array}{l}\text { Desmodium } \\
\text { triforum }\end{array}$ & Leaf & $\begin{array}{l}\text { Water soluble antioxidative silverent } \\
\text { such as ascorbic acids }\end{array}$ & Silver & $5-20 \mathrm{~nm}$ & Kesharwani et al. ${ }^{65}$ \\
\hline $\begin{array}{l}\text { Dioscorea } \\
\text { bulbifera }\end{array}$ & Leaf & Polyphenols or flavonoids & Silver & $\begin{array}{l}8-20 \mathrm{~nm} \text { Average } \\
75 \mathrm{~nm}\end{array}$ & Ahmad et al. ${ }^{66}$ \\
\hline Diopyros kaki & Leaf & Terpenoid and reducing sugars & Platinum & $2-12 \mathrm{~nm}$ & Ahire et al. ${ }^{67}$ \\
\hline $\begin{array}{l}\text { Dioscorea } \\
\text { oppositifolia }\end{array}$ & Leaf & $\begin{array}{l}\text { Polyphenols with aromatic ring and } \\
\text { bound amide region }\end{array}$ & Silver & $14 \mathrm{~nm}$ & Song et al. ${ }^{68}$ \\
\hline Dalbergia sisso & Leaf & Polyphenols or flavonoids & Gold and silver & $\begin{array}{l}5-80 \mathrm{~nm} \text { and } \\
5-55 \mathrm{~nm}\end{array}$ & Maheswari et al. ${ }^{69}$ \\
\hline $\begin{array}{l}\text { Elettaria } \\
\text { cardamomom } \\
\text { Maton }\end{array}$ & Leaf & $\begin{array}{l}\text { Alcohols, carboxylic, acids, ethers, } \\
\text { esters and aliphatic amines }\end{array}$ & Silver & - & Singh et al..$^{70}$ \\
\hline Eclipta prostrate & Leaf & Flavones and proteins & Silver & $\begin{array}{l}35-60 \mathrm{~nm} \text {, triangles, } \\
\text { pentagons, } \\
\text { hexagons }\end{array}$ & Gnanajobitha et al. ${ }^{71}$ \\
\hline $\begin{array}{l}\text { Euphorbiaceae } \\
\text { latex }\end{array}$ & Leaf & Flavonoids, proteins and terpenoids & Copper/silver & $\begin{array}{l}18 \mathrm{~nm} \text { silver and } \\
10 \cdot 5 \mathrm{~nm} \text { copper }\end{array}$ & $\begin{array}{l}\text { Rajakumar and } \\
\text { Rahuman, }^{72} \text { Patil et al. }{ }^{73}\end{array}$ \\
\hline $\begin{array}{l}\text { Emblica } \\
\text { officinalis }\end{array}$ & Leaf & Polyphenols or flavonoids & Silver and gold & $\begin{array}{l}10-20 \mathrm{~nm} \text { and } \\
15-25 \mathrm{~nm}\end{array}$ & Valodkar et al. $^{74}$ \\
\hline Euphorbia hirta & Leaf & Flavonoids & Silver & - & Ankamwar et al. ${ }^{75}$ \\
\hline $\begin{array}{l}\text { Eucalyptus } \\
\text { hybrid leaf }\end{array}$ & Leaf & Flavanoid and terpenoid & Silver & $\begin{array}{l}50-150 \mathrm{~nm} ; \\
\text { spherical }\end{array}$ & Elumalai et al. ${ }^{76}$ \\
\hline $\begin{array}{l}\text { Ficus } \\
\text { benghalensis }\end{array}$ & Leaf & Polyphenols & Silver & $16 \mathrm{~nm}$ & Dubey et al. ${ }^{77}$ \\
\hline Geranium & Leaf & Phenolics & Silver & $\begin{array}{l}\text { 16-40 nm; } \\
\text { quasilinear } \\
\text { superstructure }\end{array}$ & Jegadeeswaran et al. ${ }^{78}$ \\
\hline Gliricidia speium & Leaf & Polyphenols or flavonoids & Silver & $10-50 \mathrm{~nm}$; spherical & Shankar et al. ${ }^{79}$ \\
\hline $\begin{array}{l}\text { Gardenia } \\
\text { jasminoides } \\
\text { Ellis }\end{array}$ & Leaf & $\begin{array}{l}\text { Geniposide, chlorogenic acid, crocins } \\
\text { and crocetin }\end{array}$ & Palladium & $3-5 \mathrm{~nm}$ & Raut et al. ${ }^{80}$ \\
\hline $\begin{array}{l}\text { Glycyrrhiza } \\
\text { glabra }\end{array}$ & Leaf & Flavonoids, terpenoid, thiamine & Silver & $20 \mathrm{~nm}$ & Jia et al. ${ }^{81}$ \\
\hline $\begin{array}{l}\text { Hibiscus } \\
\text { cannabinus }\end{array}$ & Leaf & Ascorbic acid & Silver & $9 \mathrm{~nm}$ & Dinesh et al. ${ }^{82}$ \\
\hline $\begin{array}{l}\text { Hydrilla } \\
\text { verticilata }\end{array}$ & Leaf & Proteins & Silver & $65,55 \mathrm{~nm}$ & Bindhu and Umadevi ${ }^{83}$ \\
\hline Humulus lupulus & Leaf & Terpenoid & Gold & - & Sable et al. ${ }^{84}$ \\
\hline Henna & Leaf & Alkaloids, flavonoids & Gold, silver & $21,39 \mathrm{~nm}$ & Rai et al. ${ }^{85}$ \\
\hline $\begin{array}{l}\text { Hibiscus } \\
\text { rosa-sinensis }\end{array}$ & Leaf & $\begin{array}{l}\text { Polyphenols with aromatic ring and } \\
\text { bound amide region }\end{array}$ & Silver & $4 \mathrm{~nm}$; spherical & Kasthuri et al. ${ }^{86}$ \\
\hline Ipomea carnea & Leaf & Polyphenols and hydroxyl groups & Silver & $30-130 \mathrm{~nm}$ & Philip $^{87}$ \\
\hline Jatropha curcas & Leaf & $\begin{array}{l}\text { Curcacycline A (an octapeptide), } \\
\text { curcacycline B (a non-apeptide), } \\
\text { curcain (an enzyme) }\end{array}$ & Zinc sulfide, lead & $10 \mathrm{~nm} ; 10-12.5 \mathrm{~nm}$ & Daniel et al.., ${ }^{88}$ Bar et al. ${ }^{89}$ \\
\hline $\begin{array}{l}\text { Justicia } \\
\text { gendarussa }\end{array}$ & Leaf & Polyphenol and flavonoids & Gold & $27 \mathrm{~nm}$ & Hudlikar et al. ${ }^{90}$ \\
\hline $\begin{array}{l}\text { Lantana } \\
\text { camara L. }\end{array}$ & Leaf & $\begin{array}{l}\text { Carbohydrates, glycosides } \\
\text { and flavonoids }\end{array}$ & Silver & $12.55 \mathrm{~nm}$ & Fazaludeen et al. ${ }^{91}$ \\
\hline Leonuri herba L. & Leaf & Polyphenols and hydroxyl groups & Silver & $9 \cdot 9-13 \cdot 0 \mathrm{~nm}$ & Sivakumar et al. ${ }^{92}$ \\
\hline Lxora coccinea & Leaf & $\begin{array}{l}\text { Alcohols, carboxylic, acids, ethers, } \\
\text { esters and aliphatic amines }\end{array}$ & Silver & 13-57 nm; spherical & Im et al. ${ }^{93}$ \\
\hline Mentha pipertia & Leaf & Menthol & Silver, gold & 5-150 nm; spherical & $\begin{array}{l}\text { Karuppiah and } \\
\text { Rajmohan }^{94}\end{array}$ \\
\hline $\begin{array}{l}\text { Musa } \\
\text { paradisiacal }\end{array}$ & Leaf & Proteins & Silver & $20 \mathrm{~nm}$ & MubarakAli et al. ${ }^{95}$ \\
\hline $\begin{array}{l}\text { Macrotyloma } \\
\text { uniflorum }\end{array}$ & Leaf & $\begin{array}{l}\text { Polyphenols with aromatic ring and } \\
\text { bound amide region }\end{array}$ & Gold & $14-17 \mathrm{~nm}$ & Bankar et al. ${ }^{96}$ \\
\hline Mirabilis jalapa & Leaf & Polyols & Gold & $100 \mathrm{~nm}$ & Aromal et al. ${ }^{97}$ \\
\hline $\begin{array}{l}\text { Morinda } \\
\text { pubescens L. }\end{array}$ & Leaf & Hydroxyflavones, catechins & Silver & $25-50 \mathrm{~nm}$ & Vankar and Bajpai ${ }^{98}$ \\
\hline
\end{tabular}


Bioinspired, Biomimetic and Nanobiomaterials Volume 7 Issue BBN3
Mechanism of action of bio-inspired

nanosilver particles

Qurat-Ul-Ain, Sarfraz and Qayyum

Table 1. Continued

\begin{tabular}{|c|c|c|c|c|c|}
\hline Plant & Plant parts & Biomolecules involved & Type of NP & Size and shape & References \\
\hline Medicago sativa & Leaf & $\begin{array}{l}\text { Alcohols, carboxylic, acids, ethers, } \\
\text { esters and aliphatic amines }\end{array}$ & Silver & $2-20 \mathrm{~nm}$ & Jancy and Inbathamizh ${ }^{99}$ \\
\hline Memecylonedule & Leaf & Water-soluble carbohydrates & Silver and gold & $5-55,50-90 \mathrm{~nm}$ & MubarakAli et al. ${ }^{95}$ \\
\hline Morinda citrifolia & Leaf & $\begin{array}{l}\text { Phenolic compounds alcohols, } \\
\text { phenols and proteins }\end{array}$ & Silver & $32-55 \mathrm{~nm}$, oval & Parashar et al. ${ }^{100}$ \\
\hline Nerium indicum & Leaf & Polyphenols and hydroxyl groups & Silver & - & Ankamwar et al. ${ }^{75}$ \\
\hline $\begin{array}{l}\text { Nicotiana } \\
\text { tabaccum }\end{array}$ & Leaf & Proteins and amino acids & Silver & $8 \mathrm{~nm}$ & Suman et al. ${ }^{101}$ \\
\hline $\begin{array}{l}\text { Nelumbo } \\
\text { nucifera }\end{array}$ & Leaf & Protein and enzymes & Silver & $\begin{array}{l}25-80 \mathrm{~nm} \text {; spherical } \\
\text { triangular }\end{array}$ & Prasad et al. ${ }^{102}$ \\
\hline $\begin{array}{l}\text { Ocimum } \\
\text { sanctum L. }\end{array}$ & Leaf & $\begin{array}{l}\text { Phenolic and flavanoid compounds, } \\
\text { proteins, ascorbic acid, gallic acid } \\
\text { and terpenoids }\end{array}$ & Silver, gold, platinum & $\begin{array}{l}\text { Approximately } 10 \text {, } \\
4-30,23 \mathrm{~nm}\end{array}$ & $\begin{array}{l}\text { Santhoshkumar et al., }{ }^{103} \\
\text { Ahmad et al., }{ }^{104} \\
\text { Ramteke et al. }{ }^{105}\end{array}$ \\
\hline $\begin{array}{l}\text { Parthenium } \\
\text { hysterophorous }\end{array}$ & Leaf & Hydroxyflavones and catechin & Silver & $10 \mathrm{~nm}$ & Soundarrajan et al. ${ }^{106}$ \\
\hline $\begin{array}{l}\text { Pedilanthus } \\
\text { tithymaloides }\end{array}$ & Leaf & Protein and enzymes & Silver & $15-30 \mathrm{~nm}$ & Ashok Kumar ${ }^{107}$ \\
\hline Pipper betle L. & Leaf & Proteins & Silver & $3-37 \mathrm{~nm}$ & Abbasi ${ }^{108}$ \\
\hline Piper nigrum L. & Leaf & Proteins & Silver & $5-50 \mathrm{~nm}$ & Koduru et al. ${ }^{109}$ \\
\hline Plumeria rubra L. & Leaf & Proteins & Silver & $32-220 \mathrm{~nm}$ & Garg $^{110}$ \\
\hline Parthenium leaf & Leaf & Flavones and anthocyanins & Gold & $\begin{array}{l}50 \mathrm{~nm} \text {; face- } \\
\text { centered cubic }\end{array}$ & Patil et al. ${ }^{111}$ \\
\hline $\begin{array}{l}\text { Pelargonium } \\
\text { graveolens }\end{array}$ & Leaf & $\begin{array}{l}\text { Phenolic and flavanoid compounds, } \\
\text { proteins, ascorbic acid, gallic acid } \\
\text { and terpenoids }\end{array}$ & Silver & $16-40 \mathrm{~nm}$ & Parashar et al. ${ }^{112}$ \\
\hline $\begin{array}{l}\text { Phyllanthus } \\
\text { maderaspatensis }\end{array}$ & Leaf & Proteins, flavones and terpenoids & Silver & $30-130 \mathrm{~nm}$ & Shankar et al. ${ }^{113}$ \\
\hline Rosa rugosa & Leaf & Amines, alcohols & Silver, gold & $\begin{array}{l}\text { 30-60 nm silver; } \\
50-250 \mathrm{~nm} \text { gold }\end{array}$ & Annamalai et al. ${ }^{114}$ \\
\hline $\begin{array}{l}\text { Sesuvium } \\
\text { portulacastrum } \mathrm{L} \text {. }\end{array}$ & Leaf & Proteins, flavones and terpenoids & Silver & $5-20 \mathrm{~nm}$ & Dubey et al. ${ }^{115}$ \\
\hline $\begin{array}{l}\text { Solanum } \\
\text { xanthocarpum L. }\end{array}$ & Leaf & Phenolics, alkaloids and sugar & Silver & $10 \mathrm{~nm}$ & Nabikhan et al. ${ }^{116}$ \\
\hline $\begin{array}{l}\text { Sorghum bicolor } \\
\text { Moench }\end{array}$ & Leaf & Polyphenols & Silver, iron & $10 \mathrm{~nm}, 50 \mathrm{~nm}$ & Amin et al. ${ }^{117}$ \\
\hline Soybean & Leaf & Proteins and amino acids & Lead & $\begin{array}{l}\text { Approximately } \\
15 \mathrm{~nm}\end{array}$ & Njagi et al. ${ }^{118}$ \\
\hline $\begin{array}{l}\text { Swietenia } \\
\text { mahogani }\end{array}$ & Leaf & Polyhydroxy limonoids & $\begin{array}{l}\text { Silver, gold and } \\
\text { bimetallic alloy } \\
\text { gold-silver }\end{array}$ & - & Petla et al. ${ }^{119}$ \\
\hline $\begin{array}{l}\text { Syzgium } \\
\text { aromaticum }\end{array}$ & Leaf & Flavonoids & Gold & $5-100 \mathrm{~nm}$ & Mondal et al. ${ }^{120}$ \\
\hline $\begin{array}{l}\text { Sesbania } \\
\text { drummondii }\end{array}$ & Leaf & Proteins and amino acids & Gold & $6-20 \mathrm{~nm}$ & Raghunandan et al. ${ }^{121}$ \\
\hline Syzgium cumini & Leaf & Flavonoids & Silver & $100-160 \mathrm{~nm}$ & Nabikhan et al. ${ }^{116}$ \\
\hline Syzgium cumini & Bark & Proteins, flavones and terpenoids & Silver & $20-60 \mathrm{~nm}$ & Prasad and Swamy ${ }^{122}$ \\
\hline Santalum album & Leaf & Hydroxyflavones and catechins & Silver & $80-200 \mathrm{~nm}$ & Prasad and Swamy ${ }^{123}$ \\
\hline Sorghum bicolor & Leaf & Hydroxyflavones & Silver and iron & - & Swamy and Prasad ${ }^{124}$ \\
\hline Salanum torvum & Leaf & $\begin{array}{l}\text { Phenolic and flavanoid compounds, } \\
\text { proteins, ascorbic acid, gallic acid } \\
\text { and terpenoids }\end{array}$ & Silver & 5-50 nm; spherical & Njagi et al. ${ }^{118}$ \\
\hline Saraca asoca & Leaf & Hydroxyflavones and catechins & Silver & $\begin{array}{l}87-102 \mathrm{~nm} \text {, } \\
\text { irregular }\end{array}$ & Ramamurthy et al. ${ }^{125}$ \\
\hline $\begin{array}{l}\text { Terminalia } \\
\text { catappa L. }\end{array}$ & Leaf & Hydrolyzable tannins & Gold & $10-35 \mathrm{~nm}$ & Suman et al. ${ }^{101}$ \\
\hline $\begin{array}{l}\text { Trianthema } \\
\text { decandra }\end{array}$ & Leaf & Hydroxyflavones and catechins & Silver & $10-50 \mathrm{~nm}$ & Ankamwar ${ }^{126}$ \\
\hline $\begin{array}{l}\text { Tridax } \\
\text { procumbens L. }\end{array}$ & Leaf & Water-soluble carbohydrates & Copper peroxide & - & $\begin{array}{l}\text { Geethalakshmi and } \\
\text { Sarada }{ }^{127}\end{array}$ \\
\hline $\begin{array}{l}\text { Tanacetum } \\
\text { vulgare }\end{array}$ & Leaf & Hydrolysable tannins & Silver, gold & $\begin{array}{l}16 \mathrm{~nm} \text { silver, } \\
11 \mathrm{~nm} \text { gold }\end{array}$ & Annamalai et al. ${ }^{114}$ \\
\hline Trapa bispinosa & Leaf & & Silver & - & Gopalakrishnan et al. ${ }^{128}$ \\
\hline
\end{tabular}


Table 1. Continued

\begin{tabular}{|c|c|c|c|c|c|}
\hline Plant & Plant parts & Biomolecules involved & Type of NP & Size and shape & References \\
\hline $\begin{array}{l}\text { Tamarindus } \\
\text { indica }\end{array}$ & Leaf & Protein and enzymes & Gold & $20-40 \mathrm{~nm}$ & Pandey et al. ${ }^{129}$ \\
\hline Vitus vinifera L. & Leaf & Flavones and anthocyanins & Lead & $661 \mathrm{~nm}$ & Pavani et al. ${ }^{130}$ \\
\hline Vitex negundo & Leaf & Flavonoids & Gold & $\begin{array}{l}10-30 \mathrm{~nm} \text {; face- } \\
\text { centered cubic }\end{array}$ & Zargar et al. ${ }^{131}$ \\
\hline $\begin{array}{l}\text { Zingiber } \\
\text { officinale }\end{array}$ & Leaf & Alkanoids, flavonoids & Silver, gold & $10 \mathrm{~nm}$ & Singh et al. ${ }^{132}$ \\
\hline
\end{tabular}

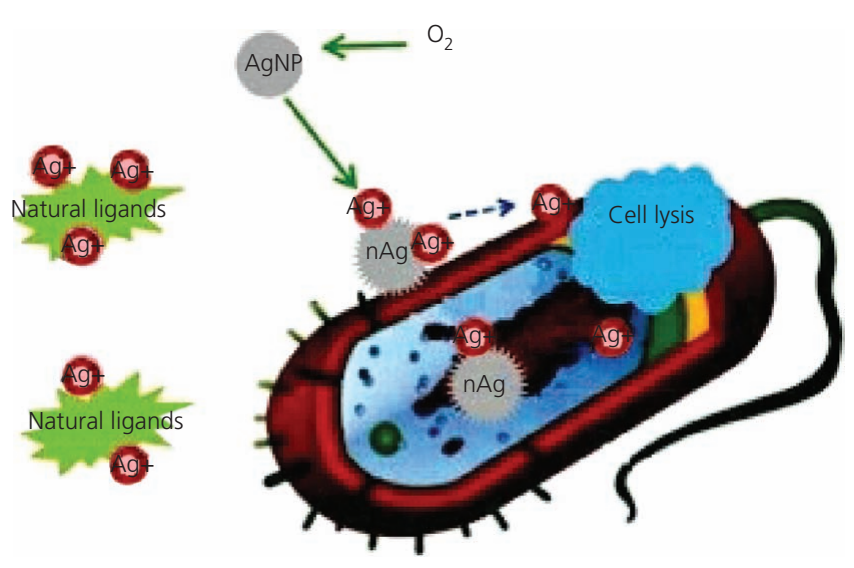

Figure 7. Mechanism of action of SNPs on microbes

the two antiparallel strands and denaturing the DNA molecule. Bacterial cell lysis could be one of the reasons for the antibacterial property of silver NPs. NPs modulate the phosphotyrosine profile of bacterial peptides, in turn affecting signal transduction and inhibiting the growth of microorganisms.

Escherichia coli cells have been treated with SNPs, and SNPs have been found to be accumulated in the bacterial membrane, which results in an increase in the permeability of the cell wall and death of the cell. Gram-positive bacteria are less susceptible to silver than gram-negative bacteria. The reason is that the grampositive bacterial cell wall has more peptidoglycan molecules than the gram-negative bacterial cell wall.

As the cell wall of gram-positive bacteria is thicker and peptidoglycans are negatively charged and silver ions are positively charged, more SNPs may get stuck to the peptidoglycans in gram-positive bacteria than in gram-negative bacteria. The decreased liability of gram-positive bacteria can also be simply explained by the fact that the cell wall of gram-positive bacteria is thicker than that of gram-negative bacteria. ${ }^{131}$

\subsection{Second mechanism}

It is proved by literature that DNA has the ability to destroy the cell membrane through an electron-release mechanism or free radical production then formation of SNPs playing a key role to make the membrane too much porous and accumulate to envelope protein precursor or destabilization of outer membrane, which finally leads to ATP leaking, which can eventually lead to cell death. ${ }^{46,137,138}$

The spectroscopic technique (electron spin resonance) has been recommended to analyze the formation of free radicals by SNPs. ${ }^{139,140}$ When bacterial cells come in contact with silver salts, the salts interact with thiol groups of many vital enzymes that exist in the cell membrane of bacteria which take up the silver ions, resulting in the inactivation of various functions in the cell and permanent injury to the cells.

Reactive oxygen species (ROS) are generated by silver ion to inhibit the respiratory enzyme of bacterial cell and attack the cell itself. Silver has a tendency to behave as an acid to react with the base present in the DNA of a cell - that is, sulfur (S) and phosphorus retarded the function of DNA ultimately causing cell death. $^{141,142}$ It is reported that phosphorylation of protein substrates in bacteria causes influences in signal transduction of bacteria and inhibition of growth. ${ }^{143}$

Silver has a potential as antiseptic and disinfectant; it has the ability to interact with disulfide bonds of the glycoprotein/protein contents of microorganisms such as viruses, bacteria and fungi. SNPs and silver ions are responsible for changing the three-dimensional structure of proteins by interfering with disulfide bonds and block the functional operations of the microorganism. ${ }^{144-146}$

Biogenically fabricated NPs are gaining importance over chemical and physical methods because it is cost-effective and eco-friendly and can be easily scaled up for large-scale synthesis, and there is no need to use high energy, pressure, temperature and toxic chemicals. $^{147-150}$

\section{Mechanism of action of SNPs toward oncogenes}

Cancer is a disease that is caused by the changes in genes that control the way cells function, particularly how they grow and divide. Genetic changes arise as the result of errors that occur in cell division because of DNA damage. In general, cancer cells have more genetic changes such as mutations in DNA than normal cells.

Akhtar et al. ${ }^{30}$ reported mechanisms in cancerous cell by using biomimetic NPs as novel controlling agents. Biogenic nanosilver 


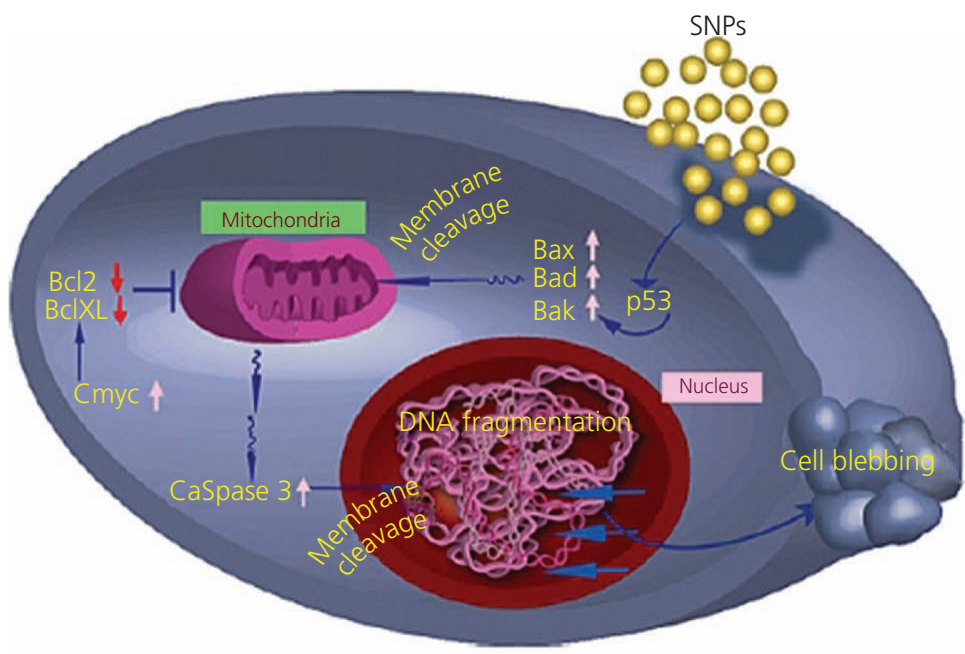

Figure 8. Mechanism of action of SNPs on oncogenes

has immense potential toward various cancer cell lines such as Hep 2, HCT 116, MCF-7, A549, HT-29 and Caco-2 (Figure 8). ${ }^{151}$

NPs, once attached to the cell membrane, damage the integrity of the membrane and trigger the activation of $\mathrm{p} 53$ protein. In turn, $\mathrm{p} 53$, a known activator of proapoptotic gene, activates Bax, Bad and Bak. These activated proteins are known to cause mitochondrial membrane leakage and release cytochrome complex, which, in a cascade reaction, activates caspase-3. Bcl-xL (B-cell lymphoma-extra large) and $\mathrm{Bcl} 2$ (B-cell lymphoma 2) are proteins in humans encoded by the Bax gene Bcl-xL, corroborating manifestation of apoptosis and consequent cell blebbing. Phytofabricated SNPs possess great selectivity to cancer cells and can display potential application in cancer chemoprevention and chemotherapy. SNPs have striking antiangiogenic properties and the ability to block the activity of abnormally expressed signaling proteins.

\subsection{In vivo mechanism of SNPs on cancerous cells}

When SNPs are exposed to certain mammalian cells, some proteins such as interleukins, macrophage colony-stimulating factor and macrophage inflammatory proteins are activated and upregulated. SNPs can stimulate inflammatory cells. They play a vital role in the formation of ROS and damage the DNA of cancer cells; this ROS depletes glutathione in rat liver cell by way of damaging the mitochondria.

SNPs have large surface area-to-mass ratio, so they can provide a large functional surface to bind, absorb and carry other compounds such as drugs, probes and protein - for example, ligands have ability to find the receptor of targeted cells. Tumor cells are usually considered more acidic in nature, so SNPs release more in tumor cells than in normal cells. Currently, an in vivo study has examined the NP distribution with diameter greater than $100-150 \mathrm{~nm}$ to accumulate in tumors because of their higher extravasation in comparison with normal vasculature. ${ }^{152-154}$
The cytostatic effect of metallic silver on cancer cells is due to active physichemical interaction of SNPs with bimolecular active functional groups of intercellular protein and DNA. SNP administration caused significant reduction of proliferation in glioblastoma multiforme (GBM) cells. ${ }^{155,156}$ Both proliferative and mitotic indices were significantly lower in the SNP group in comparison with control and placebo groups. Biogenic SNP accumulate in the nucleus of GBM cells, where they cause chromosome instability, malignancy in tumor cells and mitotic arrest. ${ }^{157}$

Medicated SNPs bind with functional groups to inhibit the overexpression of cell division and signaling cascade; SNPs have the potential ability to cure GBM against cancer. Tumor-bearing mice have a longer survival time when SNPs are injected; the effect of SNPs is more potent than that of vincristine treatment.

The SNP active surface can directly induce the generation of free radicals; it causes DNA damage and disruption of mitochondrial membrane, potentially leading to releases of cytochrome complex and mitochondria-dependent apoptosis. The majority of anticancer drugs initiate apoptosis causing caspase IX overexpression, which, after activation, leads to apoptosis.

\section{Conclusion}

Cancer is treated by using different conventional treatments such as surgery, radiotherapy and chemotherapy, which pose harmful effects on healthy tissues of the body. Biogenically fabricated SNPs have increased their importance due to its eco-friendliness. Green synthesis is now overcoming the limitations of physical and chemical methods of formations of metallic NPs. Phytofabricated nanosilver particles are less time-consuming, cost-effective and non-toxic. Silver metal has shown significant potential as an antimicrobial and anticancer agent. When silver is used as phytofabricated SNPs with increased surface area, it has enhanced efficiency against microbes and oncogenes. This current 
review has summarized the mechanisms of action of SNPs in antimicrobial and anticancer activities.

\section{REFERENCES}

1. Albrecht MA, Evans CW and Raston CL (2006) Green chemistry and the health implications of nanoparticles. Green Chemistry 8(5): 417-432.

2. Savithramma N, Rao ML, Rukmini K and Devi PS (2011) Antimicrobial activity of silver nanoparticles synthesized by using medicinal plants. International Journal of ChemTech Research 3(3): 1394-1402.

3. Feynman RP (1960) There's plenty of room at the bottom. Engineering and science 23(5): 22-36.

4. Sadowski Z (2010) Biosynthesis and application of silver and gold nanoparticles. In Silver Nanoparticles (Pozo D (ed.)). IntechOpen, London, UK, pp. 257-276.

5. Thirumurugan A, Tomy NA, Ganesh RJ and Gobikrishnan S (2010) Biological reduction of silver nanoparticles using plant leaf extracts and its effect on increased antimicrobial activity against clinically isolated organism. Der Pharma Chemica 2(6): 279-284.

6. Nalwa HS (ed.) (2005) Handbook of Nanostructured Biomaterials and Their Applications in Nanobiotechnology: Biomaterials. 1. American Scientific, Valencia, CA, USA, vol. 1.

7. Slawson RM, Trevors JT and Lee H (1992) Silver accumulation and resistance in Pseudomonas stutzeri. Archives of Microbiology 158(6): 398-404.

8. Zhao G and Stevens Jr SE (1998) Multiple parameters for the comprehensive evaluation of the susceptibility of Escherichia coli to the silver ion. Biometals 11(1): 27-32.

9. Prabhu S and Poulose EK (2012) Silver nanoparticles: mechanism of antimicrobial action, synthesis, medical applications, and toxicity effects. International Nano Letters 2(1): 1-10.

10. Kirsner R, Orsted $H$ and Wright JB (2001) The role of silver in wound healing: part 3: matrix metalloproteinases in normal and impaired wound healing. Wounds 13(3): 5-10

11. Tian J, Wong KK, Ho CM et al. (2007) Topical delivery of silver nanoparticles promotes wound healing. ChemMedChem 2(1): $129-136$

12. Haefeli C, Franklin C and Hardy K (1984) Plasmid-determined silver resistance in Pseudomonas stutzeri isolated from a silver mine. Journal of Bacteriology 158(1): 389-392.

13. Shin SH, Ye MK Kim HS and Kang HS (2007) The effects of nanosilver on the proliferation and cytokine expression by peripheral blood mononuclear cells. International Immunopharmacology 7(13): 1813-1818.

14. Altv B (2004) Nanoparticulate silver: a new antimicrobial substance for bone cement. Orthopade 33(8): 885-892.

15. Cohen MS, Stern JM, Vanni AJ et al. (2007) In vitro analysis of a nanocrystalline silver-coated surgical mesh. Surgical Infections 8(3): 397-404.

16. Kanchana A and Balakrishna M (2011) Anti-cancer effect of saponins isolated from Solanum trilobatum leaf extract and induction of apoptosis in human larynx cancer cell lines. International Journal of Pharmacy and Pharmaceutical Sciences 3(4): 356-364.

17. Thirumalai AV, Prabhu D and Soniya M (2010) Stable silver nanoparticle synthesizing methods and its applications. Journal of Biological Sciences Research 1(4): 259-270.

18. Meyers MA, Mishra A and Benson DJ (2006) Mechanical properties of nanocrystalline materials. Progress in Materials Science 51(4): 427-556.

19. Amulyavichus A, Daugvila A, Davidonis R and Sipavichus C (1998) Study of chemical composition of nanostructural materials prepared by laser cutting of metals. Fizika Metallov I Metallovedenie 85(1): $111-117$
20. Husseiny MI, El-Aziz MA, Badr Y and Mahmoud MA (2007) Biosynthesis of gold nanoparticles using Pseudomonas aeruginosa. Spectrochimica Acta Part A: Molecular and Biomolecular Spectroscopy 67(3): 1003-1006.

21. Vaidyanathan R, Gopalram S, Kalishwaralal K et al. (2010) Enhanced silver nanoparticle synthesis by optimization of nitrate reductase activity. Colloids and Surfaces B: Biointerfaces 75(1): 335-341.

22. Mohanpuria P, Rana NK and Yadav SK (2008) Biosynthesis of nanoparticles: technological concepts and future applications. Journal of Nanoparticle Research 10(3): 507-517.

23. Mukherjee P, Ahmad A, Mandal D et al. (2001) Fungus-mediated synthesis of silver nanoparticles and their immobilization in the mycelial matrix: a novel biological approach to nanoparticle synthesis. Nano Letters 1(10): 515-519.

24. Duran N, Marcato PD, Alves OL, De Souza GI and Esposito E (2005) Mechanistic aspects of biosynthesis of silver nanoparticles by several Fusarium oxysporum strains. Journal of Nanobiotechnology 3(1): $1-7$.

25. Li S, Shen Y, Xie A et al. (2007) Green synthesis of silver nanoparticles using Capsicum annuum L. extract. Green Chemistry 9(8): 852-858.

26. Saxena A, Tripathi RM and Singh RP (2010) Biological synthesis of silver nanoparticles by using onion (Allium cepa) extract and their antibacterial activity. Digest Journal of Nanomaterials and Biostructures 5(2): 427-432.

27. Sharma NC, Sahi SV, Nath S et al. (2007) Synthesis of plantmediated gold nanoparticles and catalytic role of biomatrixembedded nanomaterials. Environmental Science \& Technology 41(14): 5137-5142.

28. Chandran SP, Chaudhary M, Pasricha R, Ahmad A and Sastry M (2006) Synthesis of gold nanotriangles and silver nanoparticles using Aloe vera plant extract. Biotechnology Progress 22(2): 577-583.

29. Saxena A, Tripathi RM, Zafar F and Singh P (2012) Green synthesis of silver nanoparticles using aqueous solution of Ficus benghalensis leaf extract and characterization of their antibacterial activity. Materials Letters 67(1): 91-94.

30. Akhtar MK, Turner NJ and Jones PR (2013) Carboxylic acid reductase is a versatile enzyme for the conversion of fatty acids into fuels and chemical commodities. Proceedings of the National Academy of Sciences 110(1): 87-92.

31. Munsif V, Raghunandan K, Rama DV and Singhvi M (2011) Audit fees after remediation of internal control weaknesses. Accounting Horizons 25(1): 87-105.

32. Schaffer B, Hohenester U, Trügler A and Hofer F (2009) High-resolution surface plasmon imaging of gold nanoparticles by energy-filtered transmission electron microscopy. Physical Review $B$ 79(4): 411-419.

33. Chithrani BD, Ghazani AA and Chan WC (2006) Determining the size and shape dependence of gold nanoparticle uptake into mammalian cells. Nano Letters 6(4): 662-668.

34. Sun S, Murray CB, Weller D, Folks L and Moser A (2000) Monodisperse FePt nanoparticles and ferromagnetic FePt nanocrystal superlattices. Science 287(5460): 1989-1992.

35. Krishnaraj C, Jagan EG, Rajasekar S et al. (2010) Synthesis of silver nanoparticles using Acalypha indica leaf extracts and its antibacterial activity against water borne pathogens. Colloids and Surfaces B: Biointerfaces 76(1): 50-56.

36. Kiruba Daniel SCG, Ayyappan S, Philiphan NJP et al. (2011) Green synthesis and transfer of silver nanoparticles in a food chain through Chiranamous larva to zebra fish - A new approach for therapeutics. International Journal of Nanoscience 2: 159-169.

37. Von White G II, Kerscher P, Brown RM et al. (2012) Green synthesis of robust, biocompatible silver nanoparticles using garlic extract. Journal of Nanomaterials 2012(1-12): 730746. 
Bioinspired, Biomimetic and Nanobiomaterials Volume 7 Issue BBN3
Mechanism of action of bio-inspired

nanosilver particles

Qurat-Ul-Ain, Sarfraz and Qayyum
38. Chandran SP, Chaudhary M, Pasricha R, Ahmad A and Sastry M (2006) Synthesis of gold nanotriangles and silver nanoparticles using Aloe vera plant extract. Biotechnology Progress 22(2): 577-583.

39. Thirumurugan A, Jiflin GJ, Rajagomathi G et al. (2010) Biotechnological synthesis of gold nanoparticles of Azadirachta indica leaf extract. International Journal of Biological Technology 1: 75-77.

40. Kora AJ and Arunachalam J (2012) Green fabrication of silver nanoparticles by gum Tragacanth (Astragalus gummifer): a dual functional reductant and stabilizer. Journal of Nanomaterials 2012(1-8): 869765 .

41. Jayashree S and Vani GS (2016) In vitro study on antibacterial activity of aqueous extract and silver nanoparticles of Andrographis paniculata. International Journal of Current Microbiology and Applied Sciences 5(5): 400-406.

42. Sheny DS, Mathew J and Philip D (2011) Phytosynthesis of Au, Ag and $\mathrm{Au}-\mathrm{Ag}$ bimetallic nanoparticles using aqueous extract and dried leaf of Anacardium occidentale. Spectrochimica Acta Part A. Molecular and Biomolecular Spectroscopy 79(1): 254-262.

43. Parida UK, Bindhani BK and Nayak P (2011) Green synthesis and characterization of gold nanoparticles using onion (Allium cepa) extract. World Journal of Nano Science and Engineering 1(4): 93-98.

44. Shankar SS, Rai A Ahmad A and Sastry M (2005) Controlling the optical properties of lemongrass extract synthesized gold nanotriangles and potential application in infrared-absorbing optical coatings. Chemistry of Materials 17(3): 566-572.

45. Singh A, Jain D, Upadhyay MK, Khandelwal $N$ and Verma HN (2010) Green synthesis of silver nanoparticles using Argemone mexicana leaf extract and evaluation of their antimicrobial activities. Digest Journal of Nanomaterials and Biostructures 5(2): 483-489.

46. Ankanna S, Tollamadugu NVKVP, Elumalai EK and Savithramma N (2010) Production of biogenic silver nanoparticles using Boswellia ovalifoliolata stem bark. Digest Journal of Nanomaterials and Biostructures 5(2): 369-372.

47. Marshall AT, Haverkamp RG, Davies CE et al. (2007) Accumulation of gold nanoparticles in Brassic juncea. International Journal of Phytoremediation 9(3): 197-206.

48. Beheraa S, Mallickb B, Tiwaric TN and Mishrad PC (2011) Biosynthesis, characterization and antimicrobial studies of AgNPs extract from Bacopa monniera whole plant. Digest Journal of Nanomaterials and Biostructures 6: 135-142.

49. Jha AK and Prasad K (2010) Green synthesis of silver nanoparticles using Cycas leaf. International Journal of Green Nanotechnology: Physics and Chemistry 1(2): P110-P117.

50. Kumar V and Yadav SK (2011) Synthesis of variable shaped gold nanoparticles in one solution using leaf extract of Bauhinia variegata L. Digest Journal of Nanomaterials and Biostructures 6(4): 1685-1693.

51. Huang J, Li Q, Sun D et al. (2007) Biosynthesis of silver and gold nanoparticles by novel sundried Cinnamomum camphora leaf. Nanotechnology 18(10): 105104.

52. Sathishkumar M, Sneha K, Kwak IS et al. (2009) Phytocrystallization of palladium through reduction process using Cinnamom zeylanicum bark extract. Journal of Hazardous Materials 171(1): 400-404

53. Narayanan KB and Sakthivel N (2008) Coriander leaf mediated biosynthesis of gold nanoparticles. Materials Letters 62(30): 4588-4590.

54. Sathyavathi R, Krishna MB, Rao SV, Saritha R and Rao DN (2010) Biosynthesis of silver nanoparticles using Coriandrum sativum leaf extract and their application in nonlinear optics. Advanced Science Letters 3(2): 138-143.

55. Sathishkumar M, Sneha K and Yun YS (2010) Immobilization of silver nanoparticles synthesized using Curcuma longa tuber powder and extract on cotton cloth for bactericidal activity. Bioresource Technology 101(20): 7958-7965.
56. Kannan N, Mukunthan KS and Balaji S (2011) A comparative study of morphology, reactivity and stability of synthesized silver nanoparticles using Bacillus subtilis and Catharanthus roseus (L.) G. Don. Colloids and Surfaces B: Biointerfaces 86(2): 378-383.

57. Boruah SK, Boruah PK, Sarma P, Medhi C and Medhi OK (2012) Green synthesis of gold nanoparticles using Camellia sinensis and kinetics of the reaction. Advanced Materials Letters 3(6): 481-486.

58. Palaniselvam K, Velanganni AAJ, Govindan SN and Karthi (2012) Leaf assisted bioreduction of silver ions using leaves of Centella asiatica L. and its bioactivity. Life Sciences 1: 46-49.

59. Dwivedi AD and Gopal K (2011) Plant-mediated biosynthesis of silver and gold nanoparticles. Journal of Biomedical Nanotechnology 7(1): 163-164.

60. Vanaja M and Annadurai G (2013) Coleus aromaticus leaf extract mediated synthesis of silver nanoparticles and its bactericidal activity. Applied Nanoscience 3(3): 217-223.

61. Priya MM, Selvi BK and Paul JA (2011) Green synthesis of silver nanoparticles from the leaf extracts of Euphorbia hirta and Nerium indicum. Digest Journal of Nanomaterials and Biostructures 6(2): $869-877$.

62. He Y, Du Z, Lv H et al. (2013) Green synthesis of silver nanoparticles by Chrysanthemum morifolium Ramat. extract and their application in clinical ultrasound gel. International Journal of Nanomedicine 8(1): 1809-1815.

63. Arunachalam KD and Annamalai SK (2013) Chrysopogon zizanioides aqueous extract mediated synthesis, characterization of crystalline silver and gold nanoparticles for biomedical applications. International Journal of Nanomedicine 8(1): 2375-2384.

64. Arokiyaraj S, Arasu MV, Vincent S et al. (2014) Rapid green synthesis of silver nanoparticles from Chrysanthemum indicum $\mathrm{L}$ and its antibacterial and cytotoxic effects: an in vitro study. International Journal of Nanomedicine 9(1): 379-388.

65. Kesharwani J, Yoon KY, Hwang J and Rai M (2009) Phytofabrication of silver nanoparticles by leaf extract of Datura metel: hypothetical mechanism involved in synthesis. Journal of Bionanoscience 3(1): 39-44.

66. Ahmad N, Sharma S, Singh VN et al. (2010) Biosynthesis of silver nanoparticles from Desmodium triflorum: a novel approach towards weed utilization. Biotechnology Research International 2011: 454090

67. Ahire M, Pardesi K, Bellare J et al. (2012) Synthesis of silver nanoparticles using Dioscorea bulbifera tuber extract and evaluation of its synergistic potential in combination with antimicrobial agents. International Journal of Nanomedicine 7: 483-496.

68. Song JY, Kwon EY and Kim BS (2010) Biological synthesis of platinum nanoparticles using Diopyros kaki leaf extract. Bioprocess and Biosystems Engineering 33(1): 159-164.

69. Maheswari RU, Prabha AL, Nandagopalan V and Anburaja V (2012) Green synthesis of silver nanoparticles by using rhizome extract of Dioscorea oppositifolia $\mathrm{L}$. and their anti-microbial activity against human pathogens. Journal of Pharmaceutical and Biological Sciences 1: 38-42.

70. Singh C, Baboota RK, Naik PK and Singh H (2012) Biocompatible synthesis of silver and gold nanoparticles using leaf extract of Dalbergia sissoo. Advanced Materials Letters 3(4): 279-285.

71. Gnanajobitha G, Annadurai G and Kannan C (2012) Green synthesis of silver nanoparticle using Elettaria cardamomom and assessment of its antimicrobial activity. International Journal of Pharmaceutical Sciences and Research 3: 323-330.

72. Rajakumar G and Rahuman AA (2011) Larvicidal activity of synthesized silver nanoparticles using Eclipta prostrata leaf extract against filariasis and malaria vectors. Acta Tropica 118(3): 196-203.

73. Patil RS, Kokate MR and Kolekar SS (2012) Bioinspired synthesis of highly stabilized silver nanoparticles using Ocimum tenuiflorum leaf extract and their antibacterial activity. Spectrochimica Acta Part A: Molecular and Biomolecular Spectroscopy 91: 234-238. 
Bioinspired, Biomimetic and Nanobiomaterials Volume 7 Issue BBN3
Mechanism of action of bio-inspired

nanosilver particles

Qurat-Ul-Ain, Sarfraz and Qayyum
74. Valodkar M, Nagar PS, Jadeja RN et al. (2011) Euphorbiaceae latex induced green synthesis of non-cytotoxic metallic nanoparticle solutions: a rational approach to antimicrobial applications. Colloids and Surfaces A: Physicochemical and Engineering Aspects 384(1): 337-344.

75. Ankamwar B, Damle C, Ahmad A and Sastry M (2005) Biosynthesis of gold and silver nanoparticles using Emblica officinalis fruit extract, their phase transfer and transmetallation in an organic solution. Journal of Nanoscience and Nanotechnology 5(10): 1665-1671.

76. Elumalai EK, Prasad TNVKV, Hemachandran J et al. (2010) Extracellular synthesis of silver nanoparticles using leaves of Euphorbia hirta and their antibacterial activities. Journal of Pharmaceutical Sciences and Research 2(9): 549-554.

77. Dubey M, Bhadauria S and Kushwah BS (2009) Green synthesis of nanosilver particles from extract of Eucalyptus hybrida (safeda) leaf. Digest Journal of Nanomaterials and Biostructures 4(3): 537-543.

78. Jegadeeswaran P, Shivaraj R and Venckatesh R (2012) Green synthesis of silver nanoparticles from extract of Padina tetrastromatica leaf. Digest Journal of Nanomaterials and Biostructures 7(3): 991-998.

79. Shankar SS, Ahmad A and Sastry M (2003) Geranium leaf assisted biosynthesis of silver nanoparticles. Biotechnology Progress 19(6) 1627-1631.

80. Raut RW, Lakkakula JR, Kolekar NS, Mendhulkar VD and Kashid SB (2009) Phytosynthesis of silver nanoparticle using Gliricidia sepium (Jacq.). Current Nanoscience 5(1): 117-122.

81. Jia L, Zhang Q, Li Q and Song H (2009) The biosynthesis of palladium nanoparticles by antioxidants in Gardenia jasminoides Ellis: long lifetime nanocatalysts for p-nitrotoluene hydrogenation. Nanotechnology 20(38): 385601.

82. Dinesh S, Karthikeyan S and Arumugam P (2012) Biosynthesis of silver nanoparticles from Glycyrrhiza glabra root extract. Archives of Applied Science Research 4(1): 178-187.

83. Bindhu MR and Umadevi M (2013) Synthesis of monodispersed silver nanoparticles using Hibiscus cannabinus leaf extract and its antimicrobial activity. Spectrochimica Acta Part A: Molecular and Biomolecular Spectroscopy 101: 184-190.

84. Sable N, Gaikwad S, Bonde S, Gade A and Rai M (2012) Phytofabrication of silver nanoparticles by using aquatic plant Hydrilla verticilata. Nusantara Bioscience 4(2): 45-49.

85. Rai A, Singh A, Ahmad A and Sastry M (2006) Role of halide ions and temperature on the morphology of biologically synthesized gold nanotriangles. Langmuir 22(2): 736-741.

86. Kasthuri J, Veerapandian S and Rajendiran N (2009) Biological synthesis of silver and gold nanoparticles using apiin as reducing agent. Colloids and Surfaces B: Biointerfaces 68(1): 55-60.

87. Philip D (2010) Honey mediated green synthesis of silver nanoparticles. Spectrochimica Acta Part A: Molecular and Biomolecular Spectroscopy 75(3): 1078-1081.

88. Daniel SK, Banu BN, Harshiny M et al. (2014) Ipomea carnea-based silver nanoparticle synthesis for antibacterial activity against selected human pathogens. Journal of Experimental Nanoscience 9(2): 197-209.

89. Bar H, Bhui DK, Sahoo GP et al. (2009) Green synthesis of silver nanoparticles using latex of Jatropha curcas. Colloids and surfaces A: Physicochemical and Engineering Aspects 339(1): 134-139.

90. Hudlikar M, Joglekar S, Dhaygude M and Kodam K (2012) Latexmediated synthesis of $\mathrm{ZnS}$ nanoparticles: green synthesis approach. Journal of Nanoparticle Research 14(5): 1-6.

91. Fazaludeen MF, Manickam C, Ashankyty IM, Ahmed MQ and Beg QZ (2012) Synthesis and characterizations of gold nanoparticles by Justicia gendarussa Burm F leaf extract. Journal of Microbiology and Biotechnology Research 2(1): 23-34.

92. Sivakumar P, Nethradevi C and Renganathan S (2012) Synthesis of silver nanoparticles using Lantana camara fruit extract and its effect on pathogens. Asian Journal of Pharmaceutical and Clinical Research 5(3): 97-101.

93. Im A, Han L, Kim E et al. (2012) Enhanced antibacterial activities of Leonuri herba extracts containing silver nanoparticles. Phytotherapy Research 26(8): 1249-1255.

94. Karuppiah M and Rajmohan R (2013) Green synthesis of silver nanoparticles using Ixora coccinea leaves extract. Materials Letters 97: 141-143.

95. MubarakAli D, Thajuddin N, Jeganathan K and Gunasekaran M (2011) Plant extract mediated synthesis of silver and gold nanoparticles and its antibacterial activity against clinically isolated pathogens. Colloids and Surfaces B: Biointerfaces 85(2): 360-365.

96. Bankar A, Joshi B, Kumar AR and Zinjarde S (2010) Banana peel extract mediated novel route for the synthesis of silver nanoparticles. Colloids and Surfaces A: Physicochemical and Engineering Aspects 368(1): 58-63.

97. Aromal SA, Vidhu VK and Philip D (2012) Green synthesis of welldispersed gold nanoparticles using Macrotyloma uniflorum. Spectrochimica Acta Part A: Molecular and Biomolecular Spectroscopy 85(1): 99-104.

98. Vankar PS and Bajpai D (2010) Preparation of gold nanoparticles from Mirabilis jalapa flowers. Indian Journal of Biochemistry and Biophysics 47(3): 157-160.

99. Jancy ME and Inbathamizh L (2012) Green synthesis and characterization of nano silver using leaf extract of Morinda pubescens. Asian Journal of Pharmaceutical and Clinical Research 5(1): $159-162$

100. Parashar UK, Saxena PS and Srivastava A (2009) Bioinspired synthesis of silver nanoparticles. Digest Journal of Nanomaterials and Biostructures 4(1): 159-166.

101. Suman TY, Rajasree SR, Kanchana A and Elizabeth SB (2013) Biosynthesis, characterization and cytotoxic effect of plant mediated silver nanoparticles using Morinda citrifolia root extract. Colloids and Surfaces B: Biointerfaces 106: 74-78.

102. Prasad KS, Pathak D, Patel A et al. (2011) Biogenic synthesis of silver nanoparticles using Nicotiana tobaccum leaf extract and study of their antibacterial effect. African Journal of Biotechnology 10(41): 8122-8130.

103. Santhoshkumar T, Rahuman AA, Rajakumar G et al. (2011) Synthesis of silver nanoparticles using Nelumbo nucifera leaf extract and its larvicidal activity against malaria and filariasis vectors. Parasitology Research 108(3): 693-702.

104. Ahmad N, Sharma S, Alam MK et al. (2010) Rapid synthesis of silver nanoparticles using dried medicinal plant of basil. Colloids and Surfaces B: Biointerfaces 81(1): 81-86.

105. Ramteke C, Chakrabarti T, Sarangi BK and Pandey RA (2012) Synthesis of silver nanoparticles from the aqueous extract of leaves of Ocimum sanctum for enhanced antibacterial activity. Journal of Chemistry 2013: 1-7.

106. Soundarrajan C, Sankari A, Dhandapani P et al. (2012) Rapid biological synthesis of platinum nanoparticles using Ocimum sanctum for water electrolysis applications. Bioprocess and Biosystems Engineering 35(5): 827-833.

107. Ashok Kumar D (2012) Rapid and green synthesis of silver nanoparticles using the leaf extracts of Parthenium hysterophorus: a novel biological approach. International Research Journal of Pharmacy 3: 169-173.

108. Abbasi T, Anuradha J, Ganaie SU and Abbasi SA (2015) Biomimetic synthesis of nanoparticles using aqueous extracts of plants (botanical species). Journal of Nano Research 31: 138-202.

109. Koduru M, Dillip GR, Narasimha G, Nannepaga JS and Borelli DPR (2012) Phytofabrication and characterization of silver nanoparticles from Piper betle broth. Research Journal of Nanoscience and Nanotechnology 2(1): 17-23. 
Bioinspired, Biomimetic and Nanobiomaterials Volume 7 Issue BBN3
Mechanism of action of bio-inspired

nanosilver particles

Qurat-Ul-Ain, Sarfraz and Qayyum
110. Garg S (2012) Rapid biogenic synthesis of silver nanoparticles using black pepper (Piper nigrum) corn extract. International Journal of Innovations in Biological and Chemical Sciences 3: 5-10.

111. Patil CD, Patil SV, Borase HP, Salunke BK and Salunkhe RB (2012) Larvicidal activity of silver nanoparticles synthesized using Plumeria rubra plant latex against Aedes aegypti and Anopheles stephensi. Parasitology Research 110(5): 1815-1822.

112. Parashar UK, Saxena PS and Srivastava A (2009) Bioinspired synthesis of silver nanoparticles. Digest Journal of Nanomaterials \& Biostructures 4(1): 159-166.

113. Shankar SS, Ahmad A and Sastry M (2003) Geranium leaf assisted biosynthesis of silver nanoparticles. Biotechnology Progress 19(6): 1627-1631.

114. Annamalai A, Christina VLP, Christina V and Lakshmi PTV (2014) Green synthesis and characterisation of Ag NPs using aqueous extract of Phyllanthus maderaspatensis L. Journal of Experimental Nanoscience 9(2): 113-119.

115. Dubey SP, Lahtinen M and Sillanpää M (2010) Green synthesis and characterizations of silver and gold nanoparticles using leaf extract of Rosa rugosa. Colloids and Surfaces A: Physicochemical and Engineering Aspects 364(1): 34-41.

116. Nabikhan A, Kandasamy K, Raj A and Alikunhi NM (2010) Synthesis of antimicrobial silver nanoparticles by callus and leaf extracts from saltmarsh plant, Sesuvium portulacastrum L. Colloids and Surfaces B: Biointerfaces 79(2): 488-493.

117. Amin M, Anwar F, Janjua MRSA, Iqbal MA and Rashid U (2012) Green synthesis of silver nanoparticles through reduction with Solanum xanthocarpum L. berry extract: characterization, antimicrobial and urease inhibitory activities against Helicobacter pylori. International Journal of Molecular Sciences 13(8): 9923-9941.

118. Njagi EC, Huang $H$, Stafford L et al. (2010) Biosynthesis of iron and silver nanoparticles at room temperature using aqueous sorghum bran extracts. Langmuir 27(1): 264-271.

119. Petla RK, Vivekanandhan S, Misra M, Mohanty AK and Satyanarayana N (2012) Soybean (Glycine max) leaf extract based green synthesis of palladium nanoparticles. Journal of Biomaterials and Nanobiotechnology 3(1): 14-19.

120. Mondal S, Roy N, Laskar RA et al. (2011) Biogenic synthesis of Ag, $\mathrm{Au}$ and bimetallic $\mathrm{Au} / \mathrm{Ag}$ alloy nanoparticles using aqueous extract of mahogany (Swietenia mahogani Jacq.) leaves. Colloids and Surfaces B: Biointerfaces 82(2): 497-504.

121. Nabikhan A, Kandasamy K, Raj A and Alikunhi NM (2010) Synthesis of antimicrobial silver nanoparticles by callus and leaf extracts from saltmarsh plant, Sesuvium portulacastrum L. Colloids and Surfaces B: Biointerfaces 79(2): 488-493.

122. Prasad R and Swamy VS (2012) Antibacterial activity of silver nanoparticles synthesized by bark extract of Syzygium cumini. International Journal of Pharma and Biosciences 2012: 1-6.

123. Prasad R and Swamy VS (2013) Antibacterial activity of silver nanoparticles synthesized by bark extract of Syzygium cumini. Journal of Nanoparticles 2013: 431218.

124. Swamy VS and Prasad R (2012) Green synthesis of silver nanoparticles from the leaf extract of Santalum album and its antimicrobial activity. Journal of Optoelectronic and Biomedical Materials 4(3): 53-59.

125. Ramamurthy $\mathrm{CH}$, Padma M, Mareeswaran R et al. (2013) The extra cellular synthesis of gold and silver nanoparticles and their free radical scavenging and antibacterial properties. Colloids and Surfaces B: Biointerfaces 102: 808-815.

126. Ankamwar B (2010) Biosynthesis of gold nanoparticles (green-gold) using leaf extract of Terminalia catappa. Journal of Chemistry 7(4): 1334-1339.

127. Geethalakshmi R and Sarada DVL (2010) Synthesis of plantmediated silver nanoparticles using Trianthema decandra extract and evaluation of their anti-microbial activities. International Journal of Engineering Science and Technology 2(5): 970-975.

128. Gopalakrishnan K, Ramesh C, Ragunathan V and Thamilselvan M (2012) Antibacterial activity of $\mathrm{Cu}_{2} \mathrm{O}$ nanoparticles on $E$. coli synthesized from Tridax procumbens leaf extract and surface coating with polyaniline. Digest Journal of Nanomaterials and Biostructures 7(2): 833-839.

129. Pandey S, Mewada A, Thakur M et al. (2013) Rapid biosynthesis of silver nanoparticles by exploiting the reducing potential of Trapa bispinosa peel extract. Journal of Nanoscience 2013: 1-9.

130. Pavani KV, Swati T, Snehika V, Sravya K and Sirisha M (2012) Phytofabrication of lead nanoparticles using grape skin extract. International Journal of Engineering Science and Technology 1(4) 3376-3380.

131. Zargar M, Hamid AA, Bakar FA et al. (2011) Green synthesis and antibacterial effect of silver nanoparticles using Vitex negundo L. Molecules 16(8): 6667-6676.

132. Singh C, Sharma V, Naik PK, KHandelwal V and Singh H (2011) A green biogenic approach for synthesis of gold and silver nanoparticles using Zingiber officinale. Digest Journal of Nanomaterials and Biostructures 6(2): 535-542.

133. Klueh U, Wagner V, Kelly S, Johnson A and Bryers JD (2000) Efficacy of silver-coated fabric to prevent bacterial colonization and subsequent device-based biofilm formation. Journal of Biomedical Materials Research 53(6): 621-631.

134. Sondi I and Salopek-Sondi B (2004) Silver nanoparticles as antimicrobial agent: a case study on E. coli as a model for Gramnegative bacteria. Journal of Colloid and Interface Science 275(1): 177-182.

135. Wright JB, Lam K, Hansen D and Burrell RE (1999) Efficacy of topical silver against fungal burn wound pathogens. American Journal of Infection Control 27(4): 344-350.

136. Eby DM, Schaeublin NM, Farrington KE, Hussain SM and Johnson GR (2009) Lysozyme catalyzes the formation of antimicrobial silver nanoparticles. ACS Nano 3(4): 984-994.

137. Sharma VK, Yngard RA and Lin Y (2009) Silver nanoparticles: green synthesis and their antimicrobial activities. Advances in colloid and Interface Science 145(1): 83-96.

138. Park J, Lim DH, Lim HJ et al. (2011) Size dependent macrophage responses and toxicological effects of $\mathrm{Ag}$ nanoparticles. Chemical Communications 47(15): 4382-4384.

139. Danilczuk M, Lund A, Sadlo J, Yamada H and Michalik J (2006) Conduction electron spin resonance of small silver particles. Spectrochimica Acta Part A: Molecular and Biomolecular Spectroscopy 63(1): 189-191.

140. Kim JS, Kuk E, Yu KN et al. (2007) Antimicrobial effects of silver nanoparticles. Nanomedicine: Nanotechnology, Biology and Medicine 3(1): 95-101.

141. Morones JR, Elechiguerra JL, Camacho A et al. (2005) The bactericidal effect of silver nanoparticles. Nanotechnology 16(10): 2346 .

142. Hatchett DW and White HS (1996) Electrochemistry of sulfur adlayers on the low-index faces of silver. Journal of Physical Chemistry 100(23): 9854-9859.

143. Shrivastava S, Bera T, Roy A et al. (2007) Characterization of enhanced antibacterial effects of novel silver nanoparticles. Nanotechnology 18(22): 225103.

144. Sadeghi B and Gholamhoseinpoor F (2015) A study on the stability and green synthesis of silver nanoparticles using Ziziphora tenuior (Zt) extract at room temperature. Spectrochimica Acta Part A: Molecular and Biomolecular Spectroscopy 134: 310-315.

145. Jia X, Ma X, Wei D, Dong J and Qian W (2008) Direct formation of silver nanoparticles in cuttlebone-derived organic matrix for catalytic applications. Colloids and Surfaces A: Physicochemical and Engineering Aspects 330(2): 234-240. 
Bioinspired, Biomimetic and Nanobiomaterials Volume 7 Issue BBN3
Mechanism of action of bio-inspired

nanosilver particles

Qurat-Ul-Ain, Sarfraz and Qayyum
146. Rai M, Yadav A and Gade A (2009) Silver nanoparticles as a new generation of antimicrobials. Biotechnology Advances 27(1): 76-83.

147. Kumar PV, Pammi SVN, Kollu P, Satyanarayana KVV and Shameem U (2014) Green synthesis and characterization of silver nanoparticles using Boerhaavia diffusa plant extract and their anti-bacterial activity. Industrial Crops and Products 52: 562-566.

148. Singh M, Kumar M, Kalaivani R, Manikandan S and Kumaraguru AK (2013) Metallic silver nanoparticle: a therapeutic agent in combination with antifungal drug against human fungal pathogen. Bioprocess and Biosystems Engineering 36(4): 407-415.

149. Sahayaraj K and Rajesh S (2011) Bionanoparticles: synthesis and antimicrobial applications. In Science against Microbial Pathogens: Communicating Current Research and Technological Advances. Crop Protection Research Centre, Tamil Nadu, India, pp. 228-244.

150. Shawkey AM, Rabeh MA, Abdullah AK and Abdellatif OF (2013) Green nanotechnology: anticancer activity of silver nanoparticles using Citrullus colocynthis aqueous extracts. Advances in Life Science and Technology 13: 60-70.

151. Selim ME and Hendi AA (2012) Gold nanoparticles induce apoptosis in MCF-7 human breast cancer cells. Asian Pacific Journal of Cancer Prevention 13(4): 1617-1620.
152. Hernández-Pedro NY, Rangel-López E, Magaña-Maldonado R et al. (2013) Application of nanoparticles on diagnosis and therapy in gliomas. BioMed Research International 2013: 351031

153. Prasek M, Sawosz E, Jaworski S et al. (2013) Influence of nanoparticles of platinum on chicken embryo development and brain morphology. Nanoscale Research Letters 8(1): 251.

154. Shi Y, Wang FHEJ, Yadav S and Wang H (2010) Titanium dioxide nanoparticles cause apoptosis in BEAS-2B cells through the caspase 8/t-Bid-independent mitochondrial pathway. Toxicology Letters 196(1): 21-27.

155. Peng SF, Lee CY, Hour MJ et al. (2014) Curcumin-loaded nanoparticles enhance apoptotic cell death of U2OS human osteosarcoma cells through the Akt-Bad signaling pathway. International Journal of Oncology 44(1): 238-246.

156. Ostrovsky S, Kazimirsky G, Gedanken A and Brodie C (2009) Selective cytotoxic effect of $\mathrm{ZnO}$ nanoparticles on glioma cells. Nano Research 2(11): 882-890.

157. Zarnescu O, Brehar FM, Chivu M and Ciurea AV (2008) Immunohistochemical localization of caspase-3, caspase-9 and Bax in U87 glioblastoma xenografts. Journal of Molecular Histology 39(6): 561-569.

\section{How can you contribute?}

To discuss this paper, please submit up to 500 words to the journal office at journals@ice.org.uk. Your contribution will be forwarded to the author(s) for a reply and, if considered appropriate by the editor-in-chief, it will be published as a discussion in a future issue of the journal.

ICE Science journals rely entirely on contributions from the field of materials science and engineering. Information about how to submit your paper online is available at www.icevirtuallibrary.com/page/authors, where you will also find detailed author guidelines. 